\title{
LARGE BENTHIC FORAMINIFERA PFENDERICONUS GLOBULUS SIREL \& DECEVILER IN SIREL ET AL., 2020 (PRIABONIAN OF TURKEY): A JUNIOR SYNONYM OF PFENDERICONUS MINDANAOENSIS MATSUMARU, 2017 (THANETIAN? OF THE PHILIPPINE ARCHIPELAGO)
}

\author{
Felix Schlagintweit
}

Received: 6 September 2021 / Accepted: 27 September 2021 / Published online: 4 October 2021

\begin{abstract}
Pfendericonus mindanaoensis Matsumaru, 2017 from the Thanetian? of the Philippine Archipelago and Pfendericonus globulus Sirel \& Deceviler (in Sirel et al. 2020) from the Priabonian of Turkey display the same internal structure, similar dimensions and both are characterized by possessing wedge-like adult chambers. These species are thus considered synonymous and therefore based on priority date of publication, $P$. globulus should be considered a subjective junior synonym of $P$. mindanaoensis.
\end{abstract}

Keywords: Foraminifera, conical agglutinated taxa, taxonomy, synonymy, Paleogene

\section{INTRODUCTION}

The genus Pfendericonus represents an exclusively Paleogene genus within the group of agglutinated conical foraminifera (Hottinger \& Drobne, 1980). Within this group, Pfendericonus represents a comparatively simply structured taxon (e.g. lacking exoskeleton). Originally it was described as a subgenus of Chrysalidina later elevated to genus status by Loeblich \& Tappan (1987). The type-species is Lituonella makarskae van Soest, 1942 from the Eocene of Croatia. A second species was introduced by Hottinger \& Drobne (1980) as Chrysalidina (Pfendericonus) kahleri from the late Paleocene-early Eocene of Pakistan. Both species are high-spired (heightdiameter ratio $\mathrm{H} / \mathrm{D}>1$ ), but $P$. makarskae has a larger test and higher number of both chambers and pillars. In Recent times, two new species of globular test morphology $(\mathrm{H}=\mathrm{D})$ have been described as Pfendericonus mindanaoensis by Matsumaru (2017) and Pfendericonus globulus by Sirel \& Deceviler in Sirel et al. (2020). The present contribution deals with these two species concluding that no characters were found for distinction hence proposing their synonymy

\section{MICROPALEONTOLOGIC PART}

Pfendericonus mindanaoensis Matsumaru 2017

Fig. 1a-b

This species was described by Matsumaru (2017) from the Island of Mindanao, Philippine Archipelago and two specimens were figured. The two illustrated specimens of Chrysalidina sp. (Matsumaru, 2017, pl. 4, figs. 10-11) are here also considered to belong to $P$. mindanaoensis. The description includes a low-conical test (almost globular; diameter up to $1.36 \mathrm{~mm}$ ) displaying wedge-like chambers and a test diameter up to $1.36 \mathrm{~mm}$. The age was indicated as Selandian (= "Tertiary a0 stage of larger foraminifera" senus Matsumaru). Comparing the assemblage of this stage which includes species such as Broeckinella arabica Henson (=? Vania anatolica Sirel \& Gündüz), Coskinon rajkae Hottinger \& Drobne, Idalina sinjarica Grimsdale (Assemblage 2 in Matsumaru, 2017), a Thanetian age is more likely (e.g., Pignatti et al., 2008; Di Carlo et al., 2010).

\section{Pfendericonus globulus Sirel \& Deceviler in Sirel et al.} (2020)

Fig. 1c-d

This species was described by Sirel \& Deceviler in Sirel (2020) from the Priabonian of northwest Turkey. The description includes a subspherical (globular) test (diameter up to $1.2 \mathrm{~mm}$ ), wedge-like chambers and "incomplete spur-like septa". Other occurrences were reported from the early Oligocene of Turkey.

The following synonymy is adopted herein for Pfendericonus mindanaoensis:

Genus Pfendericonus Hottinger \& Drobne, 1980

Type-species: Lituonella makarskae van Soest, 1942

Pfendericonus mindanaoensis Matsumaru, 2017

2016 Pfendericonus aff. makarskae van Soest - SerraKiel et al., p. 54, fig. 40.8-40.15.

*2017 Pfendericonus mindanaoensis n. sp. - Matsumaru, p. 146, pl. 4, figs. 8-9, 10-11 (as Chrysalidina sp.).

2020 Pfendericonus globulus n. sp. - Sirel \& Deceviler in Sirel et al., p. 12, fig. 5pars, fig. 6E-F, fig. 11A-J.

\section{CONCLUSIONS}

Since no characters were found to clearly distinguish the two species, $P$. globulus is herein considered to be a junior synonym of $P$. mindanaoensis. Besides the occurrences in the western Pacific realm (Philippine Archipelago) and northwestern Turkey, this species might also be present in the Eocene (Bartonian-Priabonian) of Oman 

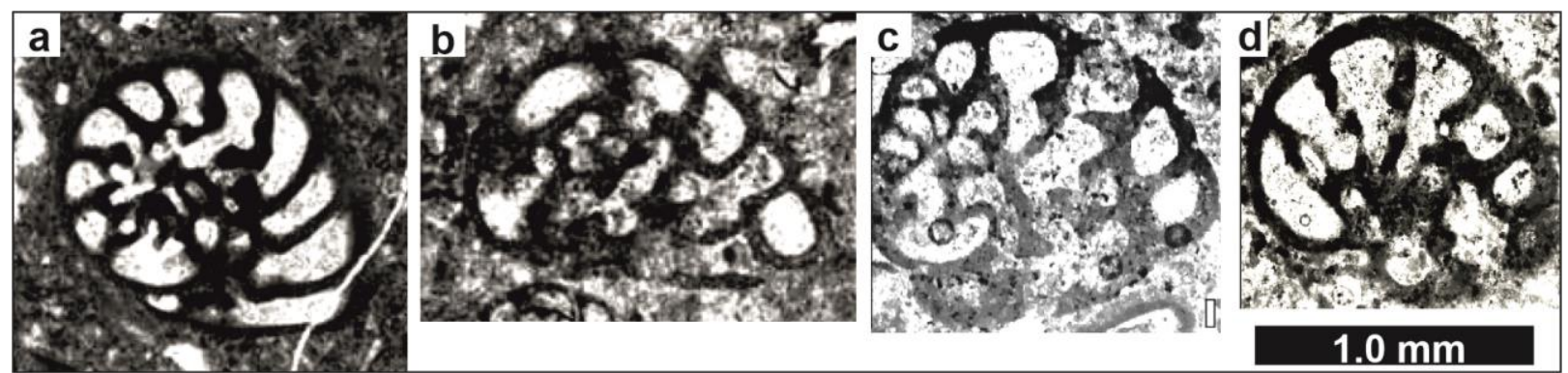

Fig. 1 a-b Pfendericonus mindanaoensis (from Matsumaru, 2017, pl. 4, fig. 11, figured as Chrysalidina sp. and pl. 4, fig. 8, holotype specimen) of Selandian or Thanetian age from the Island of Mindanao, Philippine Archipelago. c-d Pfendericonus globulus Sirel \& Deceviler (from Sirel et al., 2020, fig. 11I and 11J) from the Priabonian of NW Turkey.

where it has been recorded as Pfendericonus aff. makarskae by Serra-Kiel etal. (2016, p. 55: "possible attribution to a new species"). The comparably long stratigraphic range (Selandian?-Thanetian? to early Oligocene) is striking, also the lack of any data from the early Eocene.

\section{ACKNOWLEDGMENTS}

The two reviewers Lorenzo Consorti (Rome) and Francois Le Coze (Saint-Étienne) provided helpful comments. Michael Sandy (Deyton/Rakovski) shaped up the English.

\section{REFERENCES}

Di Carlo, M., Accordi, M., Carbone, F. \& Pignatti, J., 2010. Biostratigraphic analysis of Paleogene lowstand wedge conglomerates of a tectonically active platform margin (Zakynthos Island, Greece). Journal of Mediterranean Earth Sciences, 2: 31-92.

Hottinger, L. \& Drobne, K., 1980. Early Tertiary conical imperforate foraminifera. Razprave IV razr. SAZU, 22: $188-276$.

Loeblich, A.R., Jr. \& Tappan, H., 1987. Foraminiferal genera and their classification, Van Nostrand Reinhold, New York, 2 vol., 970 p., 847 pls.
Matsumaru, K., 2017. Larger Foraminifera from the Philippine Archipelago. Micropaleontology, 63 (2-4): 77253.

Pignatti, J., Di Carlo, M., Benedetti, A., Bottino, C., Briguglio, A., Falconi, M., Matteucci, R., Perugini, G. \& Ragusa, M., 2008. SBZ 2-6 Larger foraminiferal assemblages from the Apulian and Pre-Apulian domains. Atti del Museo civico di storia naturale di Trieste, suppl. 53: 131-146.

Serra-Kiel, J., Gallardo-Garcia, A., Razin, Ph., Robinet, J., Roger, J., Grelaud, J., Leroy, S. \& Robin, C., 2016. Middle Eocene-Early Miocene larger foraminifera from Dhofar (Oman) and Socotra Island (Yemen). Arabian Journal of Geoscience, 9: 344.

Sirel, E., Ayyildiz, T. \& Deceviler, A., 2020. Foraminifera of shallow and very shallow facies from the upper Eocene-lower Oligocene Kazandere Member, Soğucak Formation, Thrace Basin, northwest Turkey. Geologica Acta, 18.14, 1-21.

Soest, J. van., 1942. Geologie und Palaeontologie des Zentralen Biokovo (Dalmatien). Geographische en geologische Mededeelingen. Physiographisch geologische Reeks, 2 (3): 1-42 